\title{
The Effectiveness of ROR in Reading Comprehension of Narrative Text
}

\author{
Agustina Nababan ${ }^{1}$, Dewi Yana ${ }^{2}$, Sri Sugiharti ${ }^{3}$ \\ English Education Department \\ University of Riau Kepulauan \\ agustina1488@gmail.com ${ }^{1}$,alifdewi3@yahoo.com²,srisugihartiwismono@yahoo.com ${ }^{3}$
}

\begin{abstract}
The objective of this research was to know the effectiveness of Rank Ordering Retell Strategy on reading comprehension of the eight grade students' of SMP Advent Batam in academic year 2015/2016. The method was used in this research is experimental research, the research focused on True experimental Design. The population in this research was all students of eight grade students at SMP Advent Batam in academic year 2015/2016. The number of the entire students is 163. The researcher used cluster random sampling technique to determine class of the research. The subject of the study was the grade VIII - 2 and VIII - 3. There were 32 students each class. The researcher conducted research in two classes. The first class (VIII - 2) was as experiment class and the second class (VIII - 3) as control class. The experiment class was taught reading narrative text using Rank Ordering Retell Strategy, while control class was taught reading narrative text using conventional strategy (lecture method). In analyzing the data, the researcher used a quantitative measurement to find the result. The analysis of the data showed that there was a significant difference of the students' achievement before conducted treatment the average of the students' was 62.34 for experimental class and 64.22 for control class. While the average of the students' achievement after conducted treatment in experimental class was 79.38 and in control class was 68.75. Based on this finding, it can be concluded that the used of Rank Ordering Retell Strategy gave significant effect in reading comprehension than the use of conventional strategy (lecture method).
\end{abstract}

Keywords: rank ordering retell strategy, reading comprehension, narrative text.

\section{INTRODUCTION}

Reading comprehension is very important to be mastered by students. It is necessary for students because it is the basic of nearly all learning, and a basic requirement to progress in life. Reading comprehension is the ability to read text, process it and understand its meaning. In reading comprehension, the reader should be able to manage every part of the text. An individual's ability to comprehend text is influenced by their traits and skills, one of which is the ability to make inferences. Process of comprehending the students involves 
decoding the writer's word and then using background knowledge to construct and approximate understanding of the writer's message.

Based on the information from the teacher at SMP Advent Batam, the researcher known/found some problems that faced by students in reading comprehension of SMP Advent Batam itself. First the students had lack of attention in learning reading. Second, the students do not get more motivation which makes them feel interest in reading and easier to remember what they read. Third, most of students had difficulties in comprehending a reading text, especially to do their assignments in narrative text.

In relation to those problems above, there are several possible ways to help the students in reading comprehension. Meanwhile, the teacher should use various strategies, because many strategies can apply to master reading comprehension for students, one of the strategies is Rank Ordering Retell strategy.

Rank Ordering Retell strategy is developed by (Hoyt, 2002) in Macceca, (2014:179) Rank Ordering Retell strategy is a ways that effective to summary in reading activity, that is how the students selection information to determine the most important ideas, moderately important ideas, and less important ideas in reading text. We can use Rank Ordering Retell strategy in small groups or as a whole class. Rank Ordering Retell strategy can be a great way to explicit help students how inferences are developed and how they help students as a readers. The aim of the Rank Ordering Retell strategy is to help students to understand what they are reading, to help them remember the key point of the text, improving their comprehension in reading text and more easy for them to do their assignments.

Therefore in this research, the researcher was interested to used one of strategies that is Rank Ordering Retell strategy in reading comprehension, especially in narrative text. The writer chooses the topic because in the Rank Ordering Retell strategy the teacher must involve students in teaching learning process so that students can be active and will improve student's comprehension.

Based on the reason above, the researcher was interested in conducting the research on "The Effectiveness of Rank Ordering Retell Strategy in Reading Comprehension of Narrative Text at The Eight Grade Students of SMP Advent Batam in Academic Year 2015/2016.”

With reference to the background, the problem of the study is formulated as follows” is there any effectiveness of using Rank Ordering Retell strategy to students' reading 
comprehension in narrative text at eight grade of SMP Advent Batam in academic year 2015/2016?

Rosenblatt (1978) in Moreillon (2007:19) states reading as transaction among reader, the text, and the intention of the author and each reader brings own feeling, personality, and experience to the text. According to (Duke \& Pearso, 2002) in Keene, (2006:16) state reading comprehension is all process the used with complete that involving interaction between the reader and the text.

While According to (Block, Gambrell, \& Pressly, 2002) in Keene (2006:16) stated that reading comprehension is understanding message with clear so that the reader can answer a question based on the reading about the story. So reading comprehension refers to the ability to understand information presented in written form.

Reading comprehension can be defined as an active thinking process through which intentionally constructs meaning to form a deeper understanding of concepts and information present in a text. Therefore, can be concluding that, when we can say students have reading comprehension if students understand that arrangement and how it contributes to the meaning of the selection.

According to Keene (2006:18) states that assessment is the collection of data, such as test score and informal records, to measure student achievement. Afflerbach (2010:3) states that reading assessment is central to knowing students' reading progress and achievement. Reading assessment helps teachers construct understanding of how their students are developing as readers and helps us understand the strength and needs of each of our students.

Furthermore, Sencibaugh's (2007) in Westwood (2008:44) meta-analysis of reading intervention approaches shows that comprehension can indeed be improved when students are taught specially to:

a. self-monitor for understanding

b. find the main idea in a paragraph

c. self-question as they read

d. make inferences and connections

e. retell key information ( e.g. restate the gist of a paragraph )

f. Summarize key points. 
Based on the explanation above, the researcher will make the aspect in the components of assess the reading comprehension are; identifying word meaning/vocabulary from text, identifying topic, find the main idea, identifying details by questions, and make inferences.

The procedure of using Rank Ordering Retell Strategy, according to Macceca (2014:179). These below steps of using Rank Ordering Retell Strategy;

a) Teacher gives students strips of paper. After that student start a reading selection, write down phrases they consider important to the topic what they had read.

b) The students make inferred and described the information in the reading text either taken direct or indirect based on what they read with used Rank-Ordering Retell activity sheet.

c) Teacher asked students used Rank-Ordering Retell activity sheet to begin evaluating and sorting the strips into three categories: most important ideas, moderately important ideas, and less important ideas and the last,

d) Teacher ask students to identify which ideas would be the most helpful them to write a summary.

Several definition of narrative text based on experts; according to Solahudin (2013:161) based on Tutorial Writing Bahasa inggris mention narration as writing that tells us about a story. People use narrative writing when we tell a friend about something interesting that happened to you at work or in school, when you tell someone a joke, or if you write about the events of the day in the privacy of a diary or journal.

\section{METHODOLOGY}

This research used experimental research. The experimental design must be having two classes: an experimental class and another is a control class. According to Sugiyono (2014:76) explained one of true experimental design is pretest-posttest control group design. In this design, there are two groups which chosen in random (R). The first group was given the new treatment and the other group is not given the new treatment. The group which was 
given treatment called the experiment group and the group which given conventional strategy called the control group. In the real research, the effect of treatment is analyzed using differential measurement. The researcher conducted the research at the eighth grade students in SMP Advent Batam in academic year 2015/2016, which located at Jl. Teratai Blox V Nagoya Batam. The researcher conducted this research on April 2016 until finish to get the data which will then be processed to determine the effectiveness of Rank Ordering Retell strategy in reading comprehension of narrative text at the eighth grade of SMP Advent Batam in academic year 2015 / 2016. The total of population is 163 students, which consists of five classes.

This research consisted of two variables, independent variable and dependent variable. Independent variable used Rank Ordering Retell strategy and it called variable X. And dependent is student's reading comprehension in narrative text and it called variable Y.

In experimental research, subject or object which observed by researcher divided into two group. And the research involved two equal qualifications of sample group, they are an experimental and control group. The experimental group classified to Rank Ordering Retell strategy. Therefore, the experimental group provided with pre- test, treatment (Rank Ordering Retell strategy), and post- test. While the control group given pre-test, treatment (conventional strategy that is lecture method) and post -test.

\section{RESULTS}

There were 163 students registered in $8^{\text {th }}$ classes. They were grouped into five classes, but not all of them were taken as the sample. The sample of this research was VIII-2 which consists of 32 students as experimental class, and VIII-3 which consists of 32 students as control class. They were cluster random sampling. Then, experimental class was taught by using ROR (Rank Ordering Retell) strategy and conventional strategy that was lecture method used control class. At the end of the treatment, all of the samples assigned reading comprehension of narrative text test.

The data of this research was the score of students' pre-test and post-test. The researcher gave pre-test and post-test to all of samples where the students were asked to choose best answer from test or the narrative text. 
The data was obtained by giving pre-test and post-test to experimental class and control class. All of the data were analyzed to find out the maximum and minimum scores, mean scores (X) and Standard Deviation (SD) of each group. The mean score of pre-test and post-test to experimental class and control class were analyzed by using t-test to analyzing hypothesis.

Table 1. Scores of pre-test in experimental and control class

\begin{tabular}{lccccc}
\hline \multicolumn{1}{c}{ Class } & $\mathbf{N}$ & $\begin{array}{c}\text { The } \\
\text { highest } \\
\text { scores }\end{array}$ & $\begin{array}{c}\text { The } \\
\text { lowest } \\
\text { scores }\end{array}$ & Mean (X) & $\begin{array}{c}\text { Standard } \\
\text { Deviation (SD) }\end{array}$ \\
\hline Experimental & 32 & 80 & 45 & 62.34 & 7.18 \\
\hline Control & 32 & 80 & 45 & 64.22 & 7.53 \\
\hline
\end{tabular}

Table 2. Score of post-test in experimental and control class

\begin{tabular}{lccccc}
\hline \multicolumn{1}{c}{ Class } & $\mathbf{N}$ & $\begin{array}{c}\text { The } \\
\text { highest } \\
\text { score }\end{array}$ & $\begin{array}{c}\text { The } \\
\text { lowest } \\
\text { score }\end{array}$ & Mean (X) & $\begin{array}{c}\text { Standard } \\
\text { Deviation } \\
\text { (SD) }\end{array}$ \\
\hline Experimental & 32 & 95 & 85 & 79.38 & 6.81 \\
\hline Control & 32 & 60 & 50 & 68.75 & 6.96 \\
\hline
\end{tabular}

The calculation of t-test between mean score of pre-test and post-test in experimental class and control class as follow:

Calculation of t-test as follow:

$$
t=\frac{\bar{x}_{1}-\bar{x}_{2}}{\sqrt{\frac{S_{1}^{2}}{n_{1}}+\frac{S_{2}^{2}}{n_{2}}}}
$$

\section{Where:}

$\bar{X}_{1}:$ Mean of pre-test and post-test in experimental class

$\bar{X}_{2}$ : Mean of pre-test and post-test in control class 
$\mathrm{S}_{1}{ }^{2}$ : Variance of pre-test and post-test in experimental class

$\mathrm{S}_{2}{ }^{2}$ : Variance of pre-test and post-test in control class

$n_{1} \quad$ : Number of sampel experimental class

$n_{2} \quad$ : Number of sampel control class.

Mean of pre-test and post-test in experimental class

$\bar{x}_{\text {pre-test }}=\frac{\sum X}{n}=\frac{1995}{32}=62.34$

$\bar{x}_{\text {post-test }}=\frac{\sum X}{n}=\frac{2540}{32}=79.38$

So, mean of experimental class:

$\overline{X 1}=\frac{\bar{x}_{\text {pre-test }}+\bar{x}_{\text {post-test }}}{2}$

$\overline{X 1}=\frac{62.34+79.38}{2}=70.86$

Mean of pre-test and post-test in control class

$\bar{x}_{\text {pre-test }}=\frac{\sum X}{n}=\frac{2055}{32}=64.22$

$\bar{x}_{\text {post-test }}=\frac{\sum X}{n}=\frac{2200}{32}=68.75$

So, mean of control class:

$\overline{X 2}=\frac{\bar{x}_{\text {pre-test }}+\bar{x}_{\text {post-test }}}{2}$

$\overline{X 2}=\frac{64.22+68.75}{2}=66.48$

Variance of experimental class:

$\mathrm{S}^{2}{ }_{1}=\frac{S^{2}{ }_{\text {pre-test }}+S^{2} \text { post-test }^{2}}{2}$ 
$\mathrm{S}^{2}{ }_{1}=\frac{51.59+46.37}{2}=48.98$

Variance of control class:

$\mathrm{S}_{2}^{2}=\frac{S^{2} \text { pre-test }+S^{2} \text { post-test }^{2}}{2}$

$\mathrm{S}_{2}{ }_{2}=\frac{56.63+48.39}{2}=52.51$

So,

$$
\begin{gathered}
t=\frac{70.86-66.48}{\sqrt{\frac{48.98}{32}+\frac{52.51}{32}}} \\
t=\frac{4.38}{\sqrt{\frac{101.49}{32}}} \\
t=\frac{4.38}{\sqrt{3.171}} \\
t=\frac{4.38}{1.780} \\
t=2.460
\end{gathered}
$$

The value of $\mathrm{t}$ - test was 2.460, with $\mathrm{dk}=\mathrm{n}_{1}+\mathrm{n}_{2}-2(32+32)$ so, $\mathrm{dk}=62$ found $\mathrm{t}$ table $=1.66$. Based on hypothesis criteria, if $\mathrm{t}_{\text {count }}<\mathrm{t}$ table, so $\mathrm{H}_{\mathrm{o}}$ will be accepted and if $\mathrm{t}$ count $>\mathrm{t}$ table, so $\mathrm{H}_{\mathrm{a}}$ will be accepted. Where, $\mathrm{H}_{\mathrm{o}}$ explains that ROR (Rank Ordering Retell) Strategy does not give significant effect to students' reading comprehension of narrative text at eight grade of SMP Advent Batam. $\mathrm{H}_{\mathrm{a}}$ explain that ROR ( Rank Ordering Retell) Strategy give significant effect to students' reading comprehension of narrative text at eight grade of SMP Advent Batam.

\section{DISCUSSION}

ROR (Rank Ordering Retell) Strategy is a strategy was better than teaching reading comprehension by using lecture method in conventional strategy. From the data analysis 
above showed that there is significantly different. Based on the data it got highest scores of students reading competent after given treatment by using ROR (Rank Ordering Retell) Strategy in experimental class was 95, while the lowest score was 60.

The result of t- test calculation, it showed that difference between post-test in experimental class and control class. It can be conclude that ROR (Rank Ordering Retell) Strategy more effective to teach reading comprehension and can make all students active during teaching and learning process. Based on the result of the discussion derived from the data analysis presented in the previous chapter, it can be concluded that the students who were taught by using ROR (Rank Ordering Retell) strategy got better achievement than the students who were taught by using conventional (lecture method) Strategy, although the implementation is more requires a lot of time than conventional (lecture method) Strategy.

The success of this research can be proved by the students' score in the pre-test and post-test. Based on the research conducted for eight grade of the students of SMP Advent Batam in academic year 2015/2016, it can be concluded that:

1. ROR (Rank Ordering Retell) strategy was effective on students' reading comprehension. It can be seen from score both of experimental and control class in pretest and post-test. The students lowest score of control class in pre-test 45 and the highest score 80 and the students lowest score in experimental class 45 and the highest score 80 . Where, the students lowest score of control class in post-test 50 and the highest score 85 and the lowest score in experimental class in post-test 60 and the highest score 95.

2. Based on the calculation of pre-test and post-test in experimental and control class. The mean score of experimental group for pre-test was 62.34, while the mean score for post-test was 79.38. Then, the mean score of control group for pre-test was 64.22, while the mean score for post-test was 68.75. it was shown that the students who got treatments with ROR (Rank Ordering Retell) Strategy were higher score than the students who got treatments with Conventional strategy.

Based on the finding and conclusion above, the research would like to propose suggestions as follows:

1. ROR (Rank Ordering Retell) Strategy can be applied by the teachers as alternative strategy in teaching reading especially if the material focuses on reading text. 
2. ROR (Rank Ordering Retell) Strategy can be used as variation of teaching strategy in SMP Advent Batam.

3. For further research, it is suggested conduct the same research in examining the effect of ROR (Rank Ordering Retell) Strategy in wider sample in order to get the large empirical data and knowledge.

\section{REFERENCES}

Afflerbach, Peter. (2010). Essential readings assessment. USA: International Reading Association.

Keene, Ellin. (2006). Assessing comprehension thinking strategies. USA: Oceanus Drive.

Macceca, Stephanie. (2014). Reading strategies for science. USA: Shell Education.

Moreillon, Judi. (2007). Collaborative strategies for teaching reading comprehension. Chicago: America Library Association.

Sugiyono. (2013). Metode penelitian kuantitatif kualitatif dan R\& D. Bandung: Alfabeta.

Sarwoko. (2014). English on target untuk SMA/MA Kelas X. Gelora Aksara Pratama: Erlangga.

Solahudin. (2013). Tutorial writing bahasa Inggris. Banguntapan. Jogjakarta: Berlian.

Westwood, Peter. (2008). What teachers need to know about reading and writing Difficulties. Australia: Acer Press. 